\title{
Original Research \\ Do free or low-cost antibiotic promotions alter prescription filling habits?
}

\author{
Jeremy JOSLIN, Susan M. WOJCIK, Andrew FISHER, William D. GRANT
}

Received (first version): 31-Jan-2014 Accepted: 2-Aug-2014

\begin{abstract}
${ }^{*}$
Objective: Because free sample of prescription medications have been shown to influence prescribing habits of physicians, we sought to discern if promotional efforts of a retail pharmacy influenced prescriptions filled in our county after a free antibiotic program was initiated. Methods: Retrospective analysis of prescription antibiotics filled throughout the county was performed. Prescriptions filled during the first 6 months of the year before the program was initiated were compared to prescriptions filled during the first 6 months of the year immediately following initiation of the promotion.

Results: A total of 436,372 antibiotic prescriptions were dispensed during that time. The number of antibiotics filled that were included in the promotion increased by $13.4 \%$ while the number of antibiotics filled that were excluded from the promotion decreased by $20.4 \%$.

Conclusion: These data suggest that the promotional pricing of the antibiotics had a significant impact on the number of prescriptions filled in each category. Because a prescription written does not always equate to a prescription filled, further investigation is needed to confirm the relationship between these promotions and actual prescriber habits.
\end{abstract}

Keywords: Anti-Bacterial Agents; Drug Utilization; Pharmacies; Professional Practice; Physician's Practice Patterns; United States

\footnotetext{
* Jeremy JOSLIN. MD. Assistant Professor, Department of Emergency Medicine, Upstate Medical University. Syracuse, NY (United States). joslinj@upstate.edu Susan M. WOJCIK. PhD, ATC. Associate Professor, Department of Emergency Medicine, Upstate Medical University. Syracuse, NY (United States).

wojciks@upstate.edu

Andrew FISHER. BS. College of Medicine, Upstate Medical University. Syracuse, NY (United States). fishera@upstate.edu

William D. GRANT. EdD. Professor, Department of Emergency Medicine, Associate Dean Graduate Medical Education, Upstate Medical University. Syracuse, NY (United States).grantw@upstate.edu
}

\section{INTRODUCTION}

The rising cost of health care in the United States is a complex issue driven not only by the increase in the nation's average age, but also increase in the health care cost per person of these older beneficiaries. ${ }^{1-3} \mathrm{~A}$ key financial burden on patients is the cost of prescription medications. ${ }^{4}$ Since 2004 , $10 \%$ of spending in health care has been for prescription medications. ${ }^{5}$ For the uninsured and patients requiring many medications, this burden can be so significant that many patients do not adhere to the provider's specific medication instructions, resorting instead to reduced use (pill splitting, skipping intake, etc.). The financial burden of name brand prescriptions is cited as a contributor to medication nonadherance. ${ }^{6}$

Responding in a market-based sense to public concerns regarding health care expense burdens in a manner that will also serve to attract new customers, large retail pharmacies have instituted reduced cost generic prescription programs. Currently, Wal-Mart Service, Inc. dba Wal-Mart offers a 30 day supply of hundreds of over the counter medications and generic prescriptions for a USD4 flat co-pay. ${ }^{7}$ Target Corporation dba Target, CVS Caremark dba CVS, Sears Holding Company dba Kmart, and Walgreens Co. dba Walgreens all offer similar programs which include a 30-90 day supply of generic prescriptions for $\$ 4.00-12.90$ copays regardless of any other co-pays. ${ }^{8-11}$

Retail pharmacies constitute a sizable portion of the pharmaceutical dispensing market. Chain stores like CVS Caremark, Rite Aid Co. and Walgreens Co. represent $35.1 \%$ of dollars spent at pharmacies. ${ }^{12}$ Supermarket pharmacies represent another $6.9 \%$ of dollars spent at pharmacies. ${ }^{12}$ With this large of a market share, any program instituted by these locations offering select low cost prescriptions could greatly alter the prescription writing habits of physicians.

In January 2009 the Rochester, NY based grocery supermarket Wegmans Food Market dba Wegmans (79 stores in six states) instituted a low cost prescription program, offering a 14 day supply of select generic oral antibiotics for free starting January $1^{\text {st }}$ of that year; the initial program was scheduled for 3 months but was extended without interruption indefinitely. ${ }^{13}$ There were no limits on the number of prescriptions that could be filled, and it included both new prescriptions and refills. The program encompassed 9 different generic antibiotics but did not include all available antibiotics. 
Because it has been shown that free drug samples can influence the prescription writing habits of physicians $^{14-17}$, the question naturally arises whether free or deeply discounted antibiotics made available to customers would increase the amount prescribed by local physicians of these medications targeted for free distribution. A Medline (Ovid) search suggested no previous research into the topic. Therefore, we investigated if initiation of a free antibiotic program changed the proportion of prescription antibiotic class that was filled at these pharmacies.

\section{METHODS}

This study was a retrospective analysis of antibiotic prescriptions filled at selected Wegmans Food Market in-store pharmacies, a major regional supermarket chain pharmacy. Wegmans Food Market's corporate office supplied data describing antibiotic prescriptions filled during the first 6 months of the years 2008 and 2009 in Onondaga County, New York, representing 10.1\% of their stores. Data from the first 6 months of 2008 (January - June), before the program was initiated, was compared to data from the same 6 months of 2009 (January - June), after the program had been advertised and initiated. Only nine antibiotics were included under the promotional program: amoxicillin, cephalexin, sulfamethoxazole/ trimethoprim (SMT/TMP), ciprofloxacin (excluding cirprofloxacin $X R)$, penicillin VK, ampicillin, tetracycline, erythromycin stearate, erythromycin ethylsuccinate, and doxycycline hyclate (capsules).

Aggregated prescription data from Wegmans was delivered to us only by drug class: cephalosporins, macrolides, penicillins, tetracyclines, sulfonamides, and quinolones. Quinolones were further divided into ciprofloxacin, moxifloxacin, and levofloxacin. These classes were then organized for analysis by their inclusion in this promotional program. The included category contained tetracyclines, ciprofloxacin and sulfonamides. The excluded category contained levofloxacin and moxifloxacin. The macrolides, penicillins, cephalosporins were considered a mixed category since the promotional program included some drugs that were covered and some that were not.

A comparison of proportions was performed using MedCalc v11.6.1. Determination of 95\% confidence intervals for proportional differences and a p-value of 0.05 acceptance for statistical significance. Data on antibiotics with less than 500 total prescriptions filled was excluded (e.g. gemifloxacin, norfloxacin, oxyfloxacin).

\section{RESULTS}

A total of 436,372 prescriptions (214,892 from 2008 and 221,480 from 2009) were included. Table 1 lists the number of prescriptions filled relative to their inclusion or exclusion from the promotion. The number of filled prescriptions of excluded drugs decreased by $20.4 \%$ after initiation of the promotion representing a $1.53 \%$ change in all prescriptions filled $(95 \% \mathrm{Cl} 1.39 \%-1.67 \%, \mathrm{p}<0.0001)$. The number of filled prescriptions of included drugs increased by $13.4 \%$ in this period representing a $1.98 \%$ change in all prescriptions filled $(95 \% \mathrm{Cl} 1.74 \%-2.22 \%$, $\mathrm{p}<0.0001$ ). The mixed antibiotic category showed a $2.4 \%$ change representing a $0.45 \%$ increase in all prescriptions filled $(95 \% \mathrm{Cl} \quad 0.19 \%-0.71 \%$, $\mathrm{p}=0.0008$ ). Between the six month period in 2008 and the six month period in 2009 , a total number of antibiotic prescriptions filled increased by $1.6 \%$ $(p<0.0001)$.

\section{DISCUSSION}

These data suggest that the promotional pricing of the antibiotics had an impact on the number of prescriptions filled in each category. Fewer prescriptions in the excluded category of antibiotics were filled and more prescriptions in the included antibiotics were filled. Whether this represents a true difference in prescribing habits or a change in the consumers' choice in filling those prescriptions remain to be answered; however, personal experience and anecdotal observations suggest that prescribers do change their choice of antibiotics based on promotional programs. Indeed, many offices affix literature from these promotions to bulletin boards to aid in these choices.

The macrolide, penicillin, and cephalosporin antibiotic classes were placed in the mixed category due the variety of specific antibiotics included in each class. Within the macrolide class, for example, erythromycin was included in the promotion, while the heavily prescribed azithromycin was not. Within the penicillin class, similarly, penicillin was included in the promotion, while amoxicillin/clavulanate was not. Within the cephalosporin class, only cephalexin was included. Within this mixed category of antibiotics, it is conceivable that a prescriber might have been more inclined to prescribe simple

\begin{tabular}{|l|r|c|c|c|c|}
\hline \multicolumn{2}{|l|}{ Table 1. Number of prescriptions filled by category and year. } \\
\hline \multicolumn{2}{|l|}{} & 2008 Rx Count & 2009 Rx Count & $\%$ Change & p \\
\hline \multirow{2}{*}{$\begin{array}{l}\text { Included in reduced co-pay } \\
\text { program }\end{array}$} & Tetracyclins & 16,729 & 18,744 & 0.68 & $<0.0001$ \\
& Ciprofloxacin & 14,047 & 16,000 & 0.69 & $<0.0001$ \\
& Sulfonamides & 11,460 & 13,161 & 0.61 & $<0.0001$ \\
& SubTotal & 42,236 & 47,905 & 1.98 & $<0.0001$ \\
\hline \multirow{2}{*}{ Excluded from reduced co-pay } & Levofloxacin & 8,146 & 6,374 & $(0.91)$ & $<0.0001$ \\
program & Moxifloxacin & 6,315 & 5,144 & $(0.62)$ & $<0.0001$ \\
& SubTotal & 14,461 & 11,518 & $(1.53)$ & $<0.0001$ \\
\hline Mixed Antibiotics & Macrolides & 46,180 & 45,680 & $(0.87)$ & $<0.0001$ \\
& Penicillins & 79,816 & 82,017 & $(0.11)$ & 0.45 \\
& Cephalosporins & 32,199 & 34,360 & 0.53 & $<0.0001$ \\
\hline TOTAL & SubTotal & 158,195 & 162,057 & 0.45 & 0.003 \\
\hline
\end{tabular}


amoxicillin instead of amoxicillin/clavulanate when the former would be just as indicated, but more economic for a patient who has to pay out-of-pocket for the prescription to be filled. Although there are technically other sulfonamides besides trimethoprim/sulfamethoxazole (co-trimoxazole), it is unlikely that other drugs in this category represented any true significance, so we've assumed that the entirety of the drugs in this category to be included by the discount program. The volume of minocycline, and other minor tretracycline-class antibiotics, was similarly not felt to contribute to the volume of tetracyclines prescribed, nor did these others appear in our data provided by the pharmacy chain.

We believe that the growing cost of health care coupled with the emergence of low or no cost antibiotic prescription programs may have introduced a new dynamic into the prescriptionwriting decision process. Our findings of a statistically significant decrease in excluded antibiotics being filled and a statically significant increase in included antibiotics being filled offer an argument that these programs are changing the prescription writing habits of providers on some level. Another explanation is that prescribers did not necessarily change prescribing habits, but rather market share shifted from pharmacies who did not offer this specific benefit.

If prescribers did change their habits, one must wonder if this change is truly beneficial to the patient. It is likely that the inclusion or exclusion of an antibiotic for reduced/no cost co-pay by one of these retailer's programs will influence a patient's adherence to a particular prescription, especially if a prescription "falls off" the list of included drugs. At the prescriber level, it is likely that a prescription decision may be swayed by inclusion in a promotion despite a possible risk of ineffectiveness or side effect. One must wonder if antibiotic stewardship may be negatively impacted as discounted retail prices could increase the consumer's interest in being offered antibiotics for viral illnesses. Further study is needed to evaluate these questions, but the impact on public health could be significant if these programs have been eroding efforts at improving antibiotic stewardship and have, in fact, helped drive bacterial resistance.

Our data come from a particularly interesting era in US health care history. The influenza season of 2009 was significantly different than that of 2008 with the emergence of the Influenza A virus subtype $\mathrm{H} 1 \mathrm{~N} 1$ that later gained pandemic status by the World Health Organization. ${ }^{18}$ In 2007 the public's concern and awareness of methicillin-resistant Staphylococcus aureus (MRSA) reached an all-time high. ${ }^{19}$ Although prescribers have been aware of community-acquired infection (non-hospital isolates) for some time, public attention and concern seemed to peak around this time which could have placed pressure on prescribers to prescribe antibiotics for concerned patients. It is unclear how these public health phenomena influenced consumer demand of antibiotic prescriptions independent of the promotional programs. National data on antibiotic prescription rates do not correlate well with the rates we report, suggesting a local influence such as this discount program. ${ }^{20}$

Although anecdote and experience suggest a change at the provider level, our data only demonstrate a change in actual prescriptions filled at the pharmacy level. A myriad of factors play a role between the act of prescription-writing and prescription-filling such as financial abilities to fill the prescription, transportation abilities to fill the prescription, and whether the patient perceives that the prescription is even needed. Further investigation is needed to demonstrate the level at which these changes occur.

Finally, the possibility of selection bias should be considered as a reason for an increase in sales of discount prescriptions. That is, more shoppers may have utilized the stores offering discounted prescriptions, and this may have artificially increased post-implementation sales. We believe the concordant decrease in non-discounted prescriptions offers a stronger argument in favor of a true shift, however.

\section{CONCLUSIONS}

Retail promotions of antibiotic drugs do seem to alter the pattern of antibiotics filled at the pharmacy. Whether this is due to a decision by the medical provider, or driven by the consumer alone, it does appear that this promotion increased the number of covered antibiotics filled versus uncovered antibiotics. Providers who wish to increase adherence to antibiotic prescriptions should consider prescribing antibiotics covered by promotional programs when medical indication allows.

\section{ACKNOWLEDGEMENTS}

The authors would like to thank Michelle Beauchamp at Wegmans Food Market for assisting us with our data collection.

\section{CONFLICT OF INTEREST}

The authors have no conflicts of interest to report.

Funding Statement: There were no sources of funding to support this study.

\section{ALTERAN LOS ANTIBIÓTICOS GRATIS O DE BAJO COSTE LOS HÁBITOS DE PRESCRIPCIÓN O LA REPETICIÓN DE DISPENSACIÓN?}

\section{RESUMEN}

Objetivo: Como las muestras gratuitas de medicamentos de prescripción han demostrado influir en los hábitos de prescripción de los médicos, tratamos de discernir si los esfuerzos promocionales de las farmacias comunitarias influenciaban las prescripciones dispensadas en nuestro país después de iniciar un programa de antibióticos gratuitos.

Métodos: Se realizó un análisis de las recetas de antibióticos dispensadas en el condado. Las recetas dispensadas durante los 6 primeros meses del año antes del iniciar el programa se compararon con las recetas 
dispensadas durante los 6 meses del año inmediatamente posteriores a iniciar la promoción.

Resultados: Durante ese periodo, se dispensaron un total de 436.372 recetas de antibióticos. El número de antibióticos dispensaos que estaban incluidos en la promoción aumentó en un 13,4\%, mientras que el número de antibióticos dispensados que estaban excluidos de la promoción disminuyo en un 20,4\%. Conclusión: Estos datos sugieren que el marcado promocional de precios de antibióticos tiene un impacto significativo en el número de recetas dispensadas en cada categoría. Como una receta prescrita no siempre equivale a una receta dispensada, se necesita una investigación posterior para confirmar la relación entre estas promociones y los hábitos reales del prescriptor.

Palabras clave: Agentes Antibacterianos; Utilización de Medicamentos; Farmacias; Practica Profesional; Pautas en la Práctica de los Médicos; Estados Unidos

\section{References}

1. Orszag PR, Ellis $P$. The challenge of rising health care costs--a view from the Congressional Budget Office. N Engl J Med. 2007;357(18):1793-1795.

2. Orszag P. CBO Testimony: Growth in Health Care Costs. United States Senate. 1362413324 ed. 2008;:1-18.

3. Bodenheimer T. High and rising health care costs. Part 1: seeking an explanation. Ann Intern Med. 2005;142(10):847854

4. Reed M, Brand R, Newhouse JP, Selby JV, Hsu J. Coping with prescription drug cost sharing: knowledge, adherence, and financial burden. Health Serv Res. 2008;43(2):785-797. doi: 10.1111/j.1475-6773.2007.00797.x

5. Morgan S, Kennedy J. Prescription drug accessibility and affordability in the United States and abroad. Issue Brief (Commonw Fund). 2010;89:1-12.

6. Briesacher BA, Gurwitz JH, Soumerai SB. Patients at-risk for cost-related medication nonadherence: a review of the literature. J Gen Intern Med. 2007;22(6):864-871

7. \$4 Prescription Program - Walmart.com [Internet].[Available from: http://www.walmart.com/cp/PI-4Prescriptions/1078664 (Accesed 2014 Jan 13).

8. CVS/pharmacy Health Savings Pass [Internet]. [Available from: http://www.cvs.com/promo/promoLandingTemplate.jsp?promoLandingld=healthsavingspass (Accessed 2014 Jan 13)

9. Kmart Prescription Savings Account. Available from: http://www.kmart.com/kmart-pharmacy-savings-club/dap100000000246515 (Accesed 2014 Jan 13).

10. Target: Pharmacy: $\$ 4$ generic drugs listed alphabetically [Internet]. Available from: http://www.target.com/pharmacy/generics-alphabetic (Accesed 2014 Jan 13).

11. Walgreens Prescription Savings Club [Internet]. Available from: http://www.walgreens.com/pharmacy/psc/pscoverviewpage.jsp (Accesed 2014 Jan 13).

12. IMS Institute for Healthcare Informatics. The Use of Medicines in the United States: Review of 2010. Parsippany, NJ: IMS; 2011.

13. Natale J. Free Prescriptions for Oral Antibiotics at Wegmans During Cough-and-Cold Season. 2009. Available from: http://www.wegmans.com/webapp/wcs/stores/servlet/PressReleaseDetailView?storeld=10052\&catalogld=10002\&langld =-1\&productld=660835 (Accesed 2014 Jan 13).

14. Holmgren LR, Adair RF. Do drug samples influence resident prescribing behavior? A randomized trial. Am J Med. 2005;118(8):881-884.

15. Chew LD, O'Young TS, Hazlet TK, Bradley KA, Maynard C, Lessler DS. A physician survey of the effect of drug sample availability on physicians' behavior. J Gen Intern Med. 2000;15(7):478-483.

16. Pinckney RG, Helminski AS, Kennedy AG, Maclean CD, Hurowitz L, Cote E.The Effect of Medication Samples on SelfReported Prescribing Practices: A Statewide, Cross-Sectional Survey. J Gen Intern Med. 2011;26(1):40-44. doi: 10.1007/s11606-010-1483-x

17. Symm B, Averitt M, Forjuoh SN, Preece C. Effects of using free sample medications on the prescribing practices of family physicians. J Am Board Fam Med. 2006 Sep-Oct;19(5):443-449.

18. Pandemic H1N1 (2009). World Health Organization [Internet]. Available from: http://www.who.int/csr/disease/swineflu/en/ (Accessed 2014 Mar 30).

19. Google Trends - Web Search Interest: mrsa - Worldwide, 2004 - present. Available from: http://www.google.com/trends/explore\#q=MRSA (Accessed 2014 Jan 13).

20. Suda KJ, Hicks LA, Roberts RM, Hunkler RJ, Taylor TH.Trends and Seasonal Variation in Outpatient Antibiotic Prescription Rates in the United States, 2006 to 2010. Antimicrob Agents Chemother. 2014;58(5):2763-2766. doi: 10.1128/AAC.02239-13 